\title{
TV-video observations of englacial voids in Storglaciären, Sweden
}

\author{
Veijo Allan Pohjola \\ Institutionen för Geovetenskap, Uppsala Universitet, 75236 Uppsala, Sweden
}

\begin{abstract}
TV-video observations of four boreholes in Storglaciären, Sweden, revealed that $1.3 \%$ of the observed ice column was composed of englacial voids. The form of the voids is presented by photographs from the video. It is suggested that they are openings into englacial channels and cavities which were intersected during drilling. The observations further showed that about $11 \%$ of the ice column consisted of air-bubble-poor blue-ice inclusions. The observations show a relation between the blue-ice inclusions and the voids, which indicates that the origin and development of these features are coupled to each other. It is suggested that crevasses in the accumulation area are an important factor in this process.
\end{abstract}

\section{INTRODUCTION}

The character of a glacier drainage system has been discussed in theory by many authors, but reported field observations are sparse due to the physical problems of visually inspecting the interior of a glacier. This work presents images of englacial voids, discusses whether they are active parts of an englacial drainage system and discusses their probable origin.

The ability of meltwater to penetrate temperate glacier ice was first discussed during the 19th century, as reviewed by Clarke (1987). The commonly accepted idea then was that glacier ice was impermeable. Nye and Frank (1973) proposed that meltwater could drain through a network of small veins between the ice-crystal boundaries. This was further developed by Nye (1989).

Raymond and Harrison (1975) examined ice cores taken from Blue Glacier, Washington, and found such small, microscopic veins. They concluded, however, that these veins could not be solely responsible for draining all meltwater from the surface, and that there must exist more efficient water channels in the glacier. In their ice cores they found some small water passages with a diameter of a few millimeters and they suggested that, if the distribution of such passages were dense enough, they could more adequately meet the internal requirements of draining the meltwater. This agreed with observations by Mathews (1964) who inferred water-bearing cracks or passages within South Leduc Glacier, British Columbia. $\mathrm{He}$ found that effective internal drainage could not be explained solely by intergranular water flow through the glacier and suggested that water-bearing cracks or passages within the glacier must exist. Stenborg (1969) investigated this further and described such passages.

Shreve (1972) postulated that a system of englacial channels would be the principal agent of drainage within a temperate glacier. He calculated the heat produced by the water flow in englacial channels and found that larger channels would capture smaller channels. He drew an analogy with the drainage developed by karst processes and concluded that an englacial drainage system would form a dendritic pattern. This implies a large number of finger-tip tributaries at the beginning of the system, coalescing to a few main channels at the glacier front. Observations of the water flow through South Cascade Glacier, Washington, by Fountain (1992) supported Shreve's theory of a dendritic channel system.

The existence of englacial voids has been documented by investigators while drilling in glaciers. During thermal drilling it has been reported that the drill sometimes fell some distance. In some cases, the drop could be up to a few meters, and must have been a result of the drill melting itself into a void within the ice (Savage and Paterson, 1963; Shreve and Sharp, 1970; Hodge, 1976). Similar experiences occur during drilling with hot water, but in this case the voids are detected as a sudden drop of the water level in the borehole. It is observed that the water level may rise and drain again during further drilling, which gives an indication of the frequency of voids hit by the borehole. Sometimes air bubbles emerge, indicating that an air-filled cavity was intersected. Further evidence of englacial voids is given by radioecho soundings from several glaciers where return signals have been interpreted as water-filled voids or channels within the glacier body (Watts and England, 1976; Jacobel and Anderson, 1987; Bamber, 1988; Walford and Kennett, 1989). The size of the targets in these observations was estimated to be between decimeters and $1 \mathrm{~m}$ in diameter.

The short review above inevitably creates a question: is there any coupling between the voids and the inferred englacial passages? An attempt to answer this question is made by discussing observations made in Storglaciären, Sweden. 


\section{Storglaciären}

Storglaciären, a temperate valley glacier with a perennial cold surface zone (Holmlund and Eriksson, 1989), is situated in the Kebnekaise massif, Swedish Lappland (Fig. 1). The hydrological character of Storglaciären has been described by several investigators (Stenborg, 1965, 1969, 1973; Holmlund and Hooke, 1983; Holmlund, 1988a, b; Hooke and others, 1988, 1989, 1990; Seaberg and others, 1988; Hooke, 1991) and the general character of the glacier has been described by Schytt (1959) and Holmlund (1987).

Stenborg (1973) observed that a major riegel in the bedrock, which traverses the tongue at about $1350 \mathrm{~m}$ a.s.l. (see Fig. 1), complicated the internal drainage through the glacier. Hooke (1991) suggested that the principal drainage through the overdeepening up-glacier of the riegel is forced to become englacial, due to the adverse bottom topography. This suggests a high degree of internal porosity and permeability to be able to drain the water input from the accumulation area through englacial pathways. The observation of englacial water bodies or channels by Walford and Kennett (1989) from radio-echo experiments on Storglaciären is an indication of the internal porosity. Furthermore, drainage during drilling has been used to infer that a borehole intersected

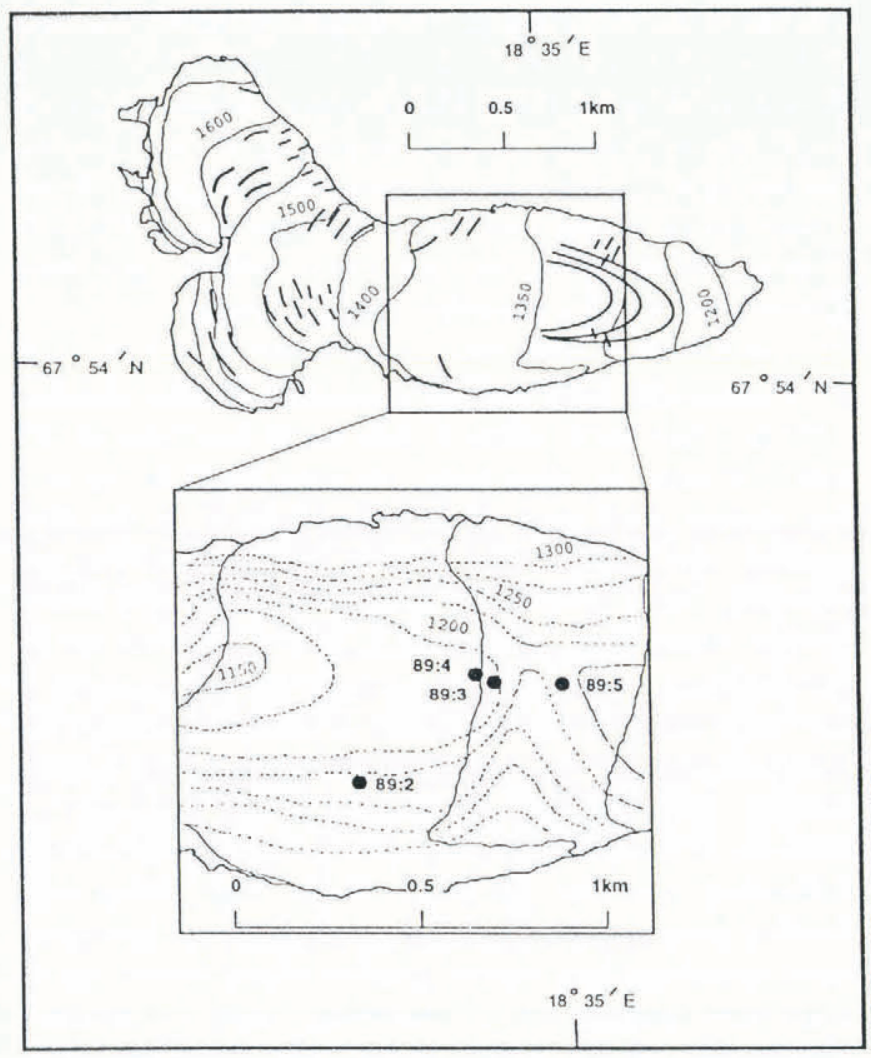

Fig. 1. Storglaciären, with an inset showing the four boreholes inspected by TV-video in 1989. Surface topography from Holmlund (1987). Bed topography shown in the inset is after Björnsson (1981). Crevassed areas are drawn as short black lines on the glacier surface. The arcs drawn between 1250 and $1350 \mathrm{~m}$ a.s.l. show the area where arcuate blue-ice banding is frequent. Note that the drawn arcs and crevasses do not show the positions of single features. an englacial drainage system. Of 47 boreholes drilled in this area $66 \%$ drained englacially (Hooke, 1991). These boreholes were presumed to be connected to an englacial drainage system, due to measured water-level fluctuations with time and to dye-tracer experiments (Hooke and others, 1989; Hooke, 1991).

\section{OBSERVATIONS}

The principal objective of the video inspection of boreholes was to investigate the bed beneath Storglaciären (Pohjola, 1993), but abundant information about the englacial environment was also obtained during these observations. Four holes were drilled using standard hot-water drilling methods. The camera had an almost hemispherical viewing coverage, with a rotation of more than $220^{\circ}$ in the horizontal plane and up to $85^{\circ}$ in the vertical plane. The motion and focusing of the camera were controlled from the surface. During lowering of the camera to the bed, more careful inspections were made when features of interest appeared on the borehole wall. Thickness of inspected features was measured by using a depth counter attached to the cable wheel. Inspections of the wall, from the surface to the bed, were possible in two boreholes, but high turbidity at depth precluded detailed observations in the deepest parts. The other two boreholes were too narrow at their basal parts to allow entrance by the camera to the bed.

To present visually the information given by the video record, photographs were taken from a TV screen. The video camera used was equipped with a fish-eye lens (1:1.8), which made it impossible to use an exact scale and consequently no scale bars are shown on the photographs. To determine an approximate scale, two objects of relatively known size can be used: the borehole diameter in overview scenes, with a size of about $20 \mathrm{~cm}$; the air bubbles in close-up scenes, with a size of about $2 \mathrm{~mm}$.

During the inspection of the four boreholes, many englacial features were observed on the borehole walls. The observed features can be divided into five groups: 1 . Foliation bands; 2. Englacial debris; 3. An anomalous "deep ice"; 4. Blue-ice inclusions; 5. Englacial voids. A detailed presentation of features $1-3$ is not presented here; however, a few general observations can be made. Foliation bands and blue-ice inclusions are both composed of clear ice with a low air-bubble content. Foliation bands are defined here as blue-ice layers with a thickness less than $0.1 \mathrm{~m}$. The general thickness of foliation bands was less than a centimeter and therefore often difficult to find on the ice wall.

Very little debris was detected in the borehole walls. All the observations, with one exception (Fig. 2a and b), were of sporadically distributed rocks (Fig. $2 \mathrm{c}$ and d), and indicate that the observed ice was almost free from debris. However, it should be repeated that the visibility in the deepest parts of the boreholes was poor. A higher concentration of debris could possibly have existed there.

An ice type of a different character occurred in the lowermost 25-40 m of the four boreholes. This "deep ice" appears to consist of much coarser crystals, a lower density of air bubbles and had a darker shade than the 
Pohjola: TV-video observations of englacial voids in Storglaciären, Sweden

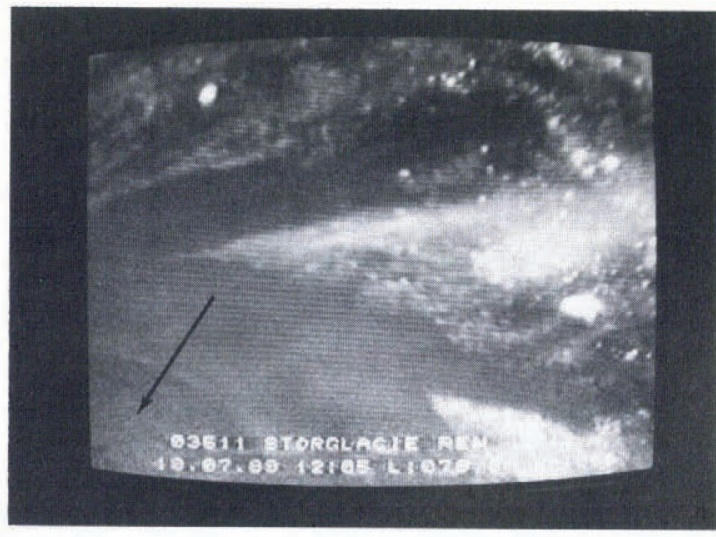

a

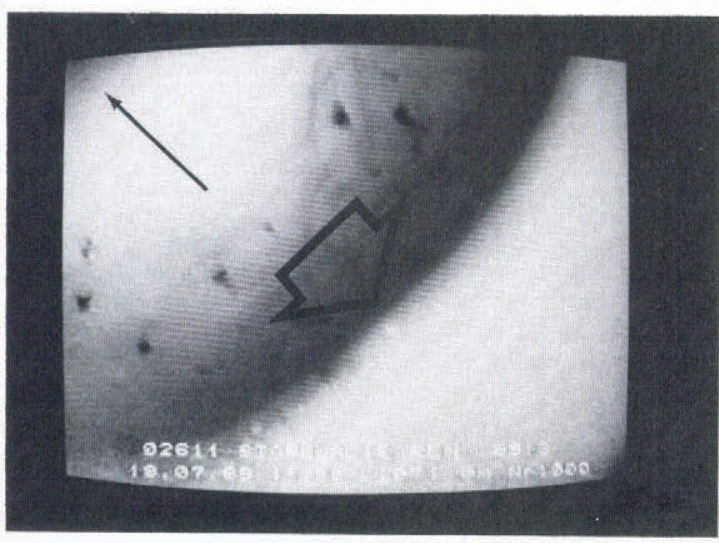

c

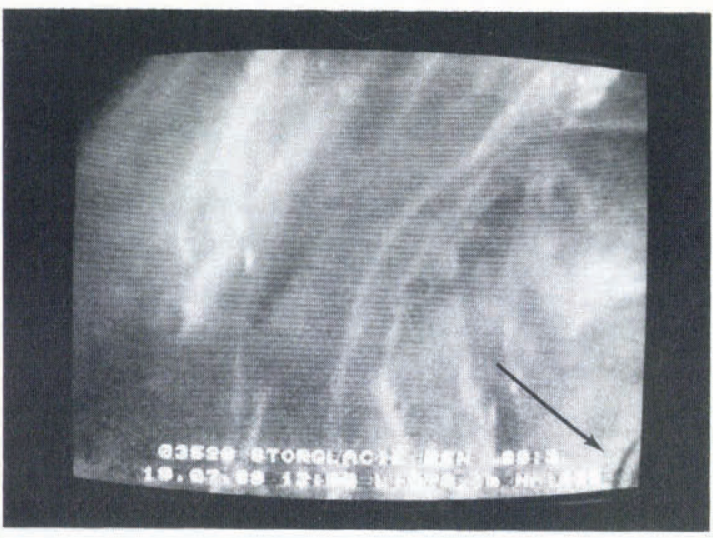

b

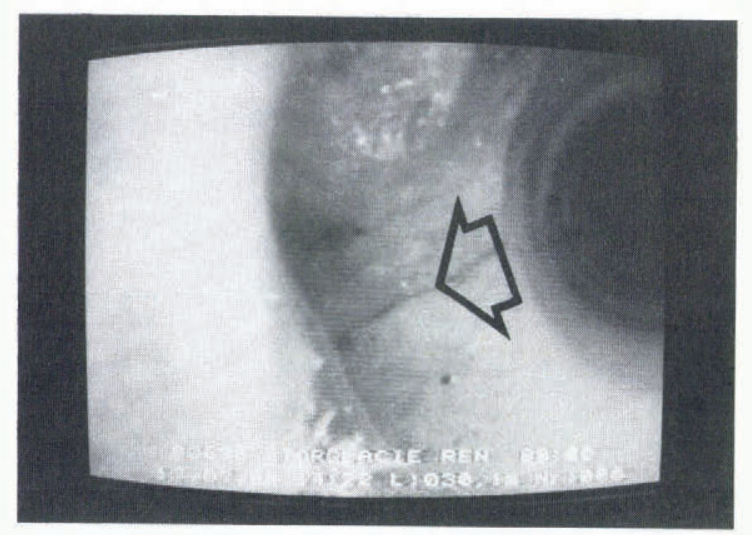

d

Fig. 2. Photographs of englacial debris. The thin arrow points to the bed. a. Borehole $89: 3,78.9 \mathrm{~m}$ depth. This scene shows englacial debris layered in sedimentary sequences within a blue-ice inclusion (see Fig. 5d). The dark massive areas are blue ice and the lighter areas are debris interlayered with air bubbles. The debris/bubble layers are inclined at about $45^{\circ}$ from the horizontal plane. (The debris is difficult to detect in a black-and-white print but in the color video the debris was observed to have a reddish shade.) The layering may indicate aquatic deposition in a former englacial channel. $b$. Borehole 89:3, $79.1 \mathrm{~m}$ depth. This shows the debris layers located at the opposite aspect of the wall shown in Figure $2 a$. The light-gray plumes are debris layers. c. Borehole 89:3, 71.0 m depth. This scene shows a close-up of the same cleavage as shown in Figure 7a. At the floor of the opening, dark grains of debris are observed. d. Borehole 89:2, 30.1 m depth. A tubular opening with a few debris grains on the floor of the opening.

overlying ice. The limit between the overlying ice and the "deep ice" was, in one borehole, observed to be sharp.

\section{Blue-ice inclusions}

The term blue-ice inclusion is used for all structures which were composed of clear, almost bubble-free ice, and which had a thickness greater than $0.1 \mathrm{~m}$. Some blue-ice inclusions were merely thick foliation bands, which had symmetrical dimensions all around the borehole transection (Fig. 3a). Others were very asymmetrical in their form (Fig. 3b). Some inclusions had vertical dimensions of up to $2 \mathrm{~m}$ (see Fig. 4). Approximately $11 \%$ of the total observed column of glacier ice was composed of blue ice, excluding foliation bands.

Many of the blue-ice inclusions had a sharp boundary with air-bubble-rich white ice (Figs $3 c$ and $5 a-c$ ), but in some cases the bubble concentration gradually decreased into the blue-ice area, as shown in Fig. 3d.

\section{Englacial voids}

Several openings in the borehole walls were observed, showing a variety of shapes and sizes. The location and their approximate size are given in Table 1 and in Figure 4.

The smallest openings that were observed in the borehole walls could be described as voids fretted into the ice. These forms always appeared at the point of contact between white ice and blue ice (inclusions or foliation bands), where white ice overlaid blue ice (Fig. 6). In this work they will be referred to as "jagged forms". These openings were of centimeter to decimeter size; in many cases, they were grouped together as several small openings in a restricted area.

A second type of opening was clearly confined tubular openings of about $1 \mathrm{dm}$ in diameter (Figs $2 \mathrm{~d}$ and 5). Some were situated within thick blue-ice inclusions and others had just a thin layer of blue ice around the channel. The third type were horizontal cleavages (Fig. 7). The openings were in some cases so wide that their horizontal limit could not be observed. The horizontal cleavages were not attributed to blue ice. The final type of opening were vertical cleavages. They were typically a couple of centimeters wide, but with a vertical dimension of several decimeters. An extensive version of this form was found in 


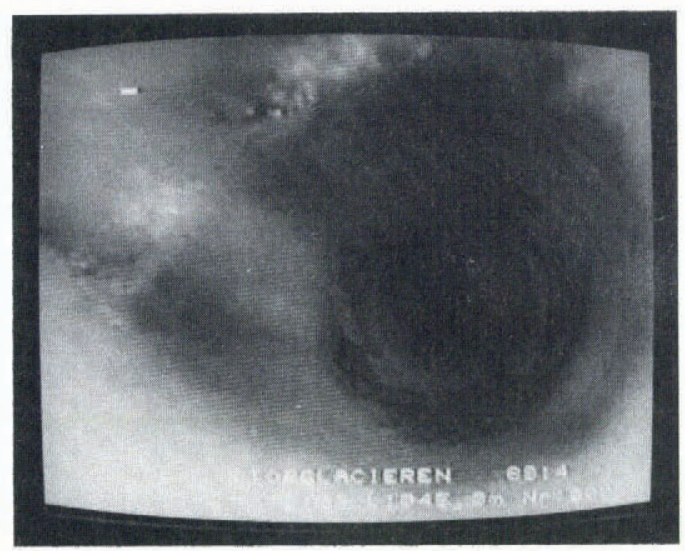

a

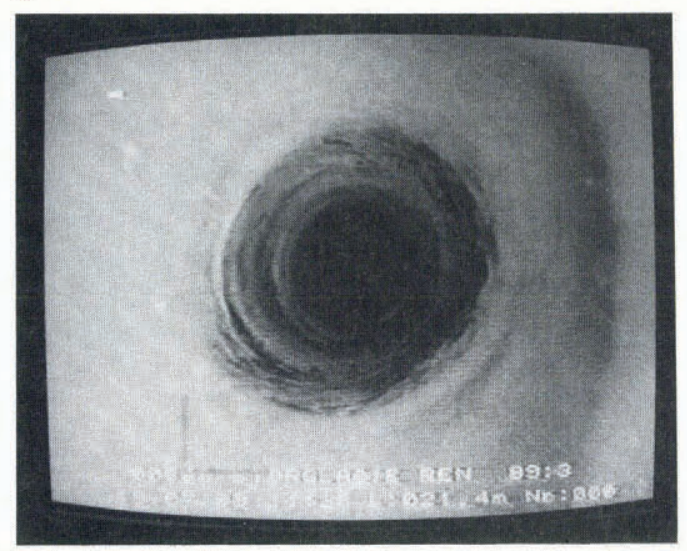

c

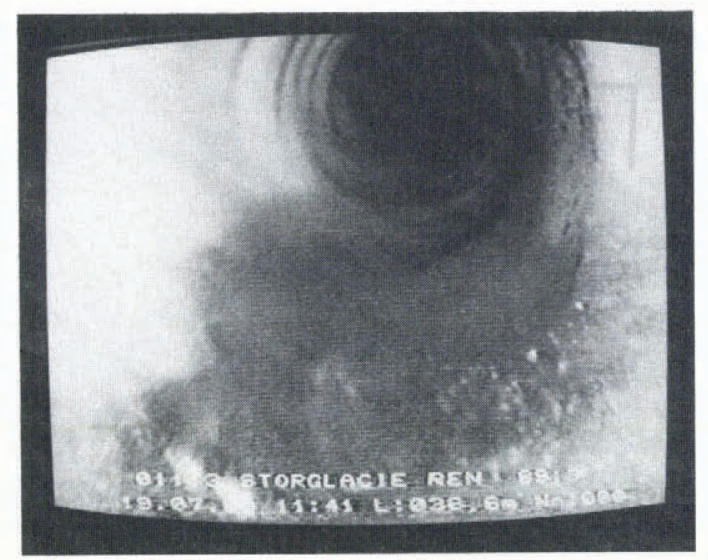

b

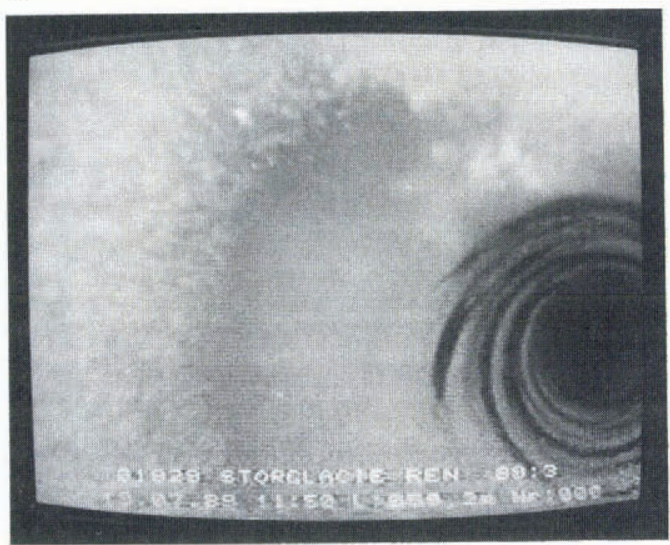

d

Fig. 3. Photographs of blue-ice inclusions. The camera is looking down into each borehole. a. Borehole 89:4, 45.3 m depth. A symmetrical blue-ice inclusion is shown which occurs all around the wall. The darker area contains blue ice and the lighter area is bubbly white ice. The inclusion is tilted at about $70^{\circ}$ from the horizontal plane, which is similar to the tilt found on foliation bands in this area. $b$. Borehole 89:3, 36.6 m depth. Example of an asymmetrical blue-ice inclusion. This inclusion occupies one-third of the borehole wall. c. Borehole 89:3, 21.3m depth. Example of a sharp boundary between white-ice and blue-ice areas. $d$. Borehole 89:3, 59.2 $m$ depth. Example of a gradual alteration from white ice to blue ice.

borehole 89:5 where an open crevasse was intersected by the borehole at a depth of $27 \mathrm{~m}$ (Fig. 8).

In total, 14 voids were observed during inspection of the video recordings. All of the jagged and tubular forms were associated with blue ice. Of the cleavage forms, only one had any appreciable amount of blue ice. The size of these voids can be used to estimate the internal void ratio in the ice of the observed area. Using the vertical dimensions from Table 1, and assuming that all jagged forms had a vertical dimension of $0.1 \mathrm{~m}$, this gives a void ratio of $1.3 \%$. The parts of the ice column with limited visibility are omitted from this calculation.

\section{DISGUSSION}

Clearly, a degree of porosity is shown by the video inspections, but were the voids observed here linked to any englacial water system, or were they isolated within the glacier? Several approaches were taken to address this question.

Observations were made to determine whether the openings had any counterpart on the opposite aspect of the wall. In at least ten of the 14 observed voids a corresponding opening was found. In the case of jagged forms, several openings often appeared grouped together, and in the case of horizontal cleavages the opening was present all around the borehole perimeter.

Water movement through the borehole between openings was investigated by tying a nylon string on to a frame in front of the camera, and then suspending this level with the openings. Any movement of the string was observed and interpreted as water flow. Movement was detected in just one of the 14 openings; this was at $71 \mathrm{~m}$ in borehole 89:3. From an opening at $78 \mathrm{~m}$ in the same borehole it was possible to observe how a particle came out from the opening and fell into the borehole (see Fig. 5d). Dye-tracer experiments in boreholes in this area of Storglaciären suggest water speeds in englacial conduits to be within the order of $0.01-0.1 \mathrm{~m} \mathrm{~s}^{-1}$ (Hooke and others, 1988), which is about the same magnitude of velocity observed by the particle in borehole $89: 3$. This low water velocity may explain why the string did not detect any movement; the string may have been too stiff to detect such small velocities.

Another approach was to compare the drill depth when the water level dropped during drilling with the depth of the observed voids. Boreholes $89: 3,4$ and 5 were found to have drained at the level of the most pronounced void in each borehole (Fig. 4; Table 1). Borehole 89:2 never drained during drilling but drained the following 


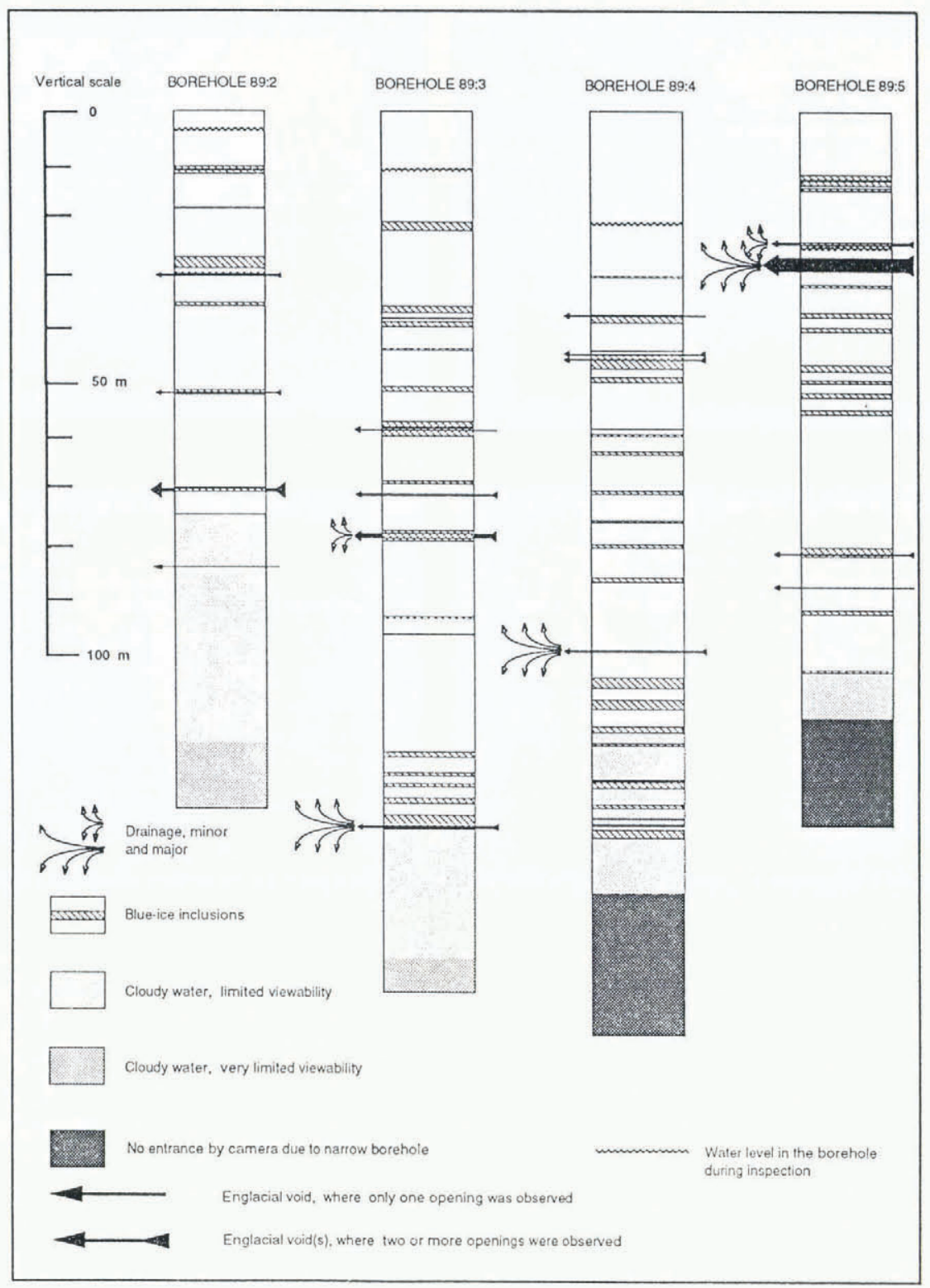

Fig. 4. Illustration of features observed by TV-video inspection. The borehole sections are one-dimensional, showing an idealized picture of the observed features, and do not show their real appearance on the borehole wall. Major drainage symbolizes where the drill punctured a void, resulting in a drop of the water level in the borehole to the level shown in the illustration. Minor drainage symbolizes a condition where drainage capacity was lower than the water input from the drill.

night. Drainage in borehole 89:5 was through an intersected crevasse.

A final approach was to study the upwelling of cloudy water from the bed. This shows that the borehole is an artificial conduit between the subglacial and englacial water systems in this area. Figure 4 illustrates that the limit between clean and cloudy water lies at the level of a pronounced opening in boreholes 89:2 and 89:3. In the case of borehole $89: 3$, this was also the level at which the borehole drained. This indicates that subglacial water moves into the borehole and out through some englacial channel. A similar conclusion was drawn from conductivity measurements in boreholes (Hooke and others, 1988).

Before proceeding, it must be considered whether hot water from the drill affected the morphology of the openings. In many cases, one of the openings was clearly defined as a smoothed opening, while the corresponding opening on the opposite aspect of the wall was more diffuse in character, if observed at all (e.g. see Figs 4 and $5 \mathrm{a}-\mathrm{c})$. One explanation is that the borehole cut through the outer part of the void, but the probability that this might explain all cases is low. A better explanation for this is that one of the openings was smoothed by hot water during drilling. The direction of water movement can be deduced from the fact that only one of the openings was enlarged.

Now, turning to the question stated in the introduction: whether the observed voids are synonymous with englacial channels. The voids observed at the level where the boreholes drained during drilling must be connected to an hydraulical system. If smoothing of one of the openings is regarded as evidence of drainage to an active channel system, then most of the observed voids are englacial channels. The reason that these channels did not drain the borehole is presumably because their total drainage capacity was lower than the influx of water from the drill (about $101 \mathrm{~min}^{-1}$ ) or that they had a pressure 

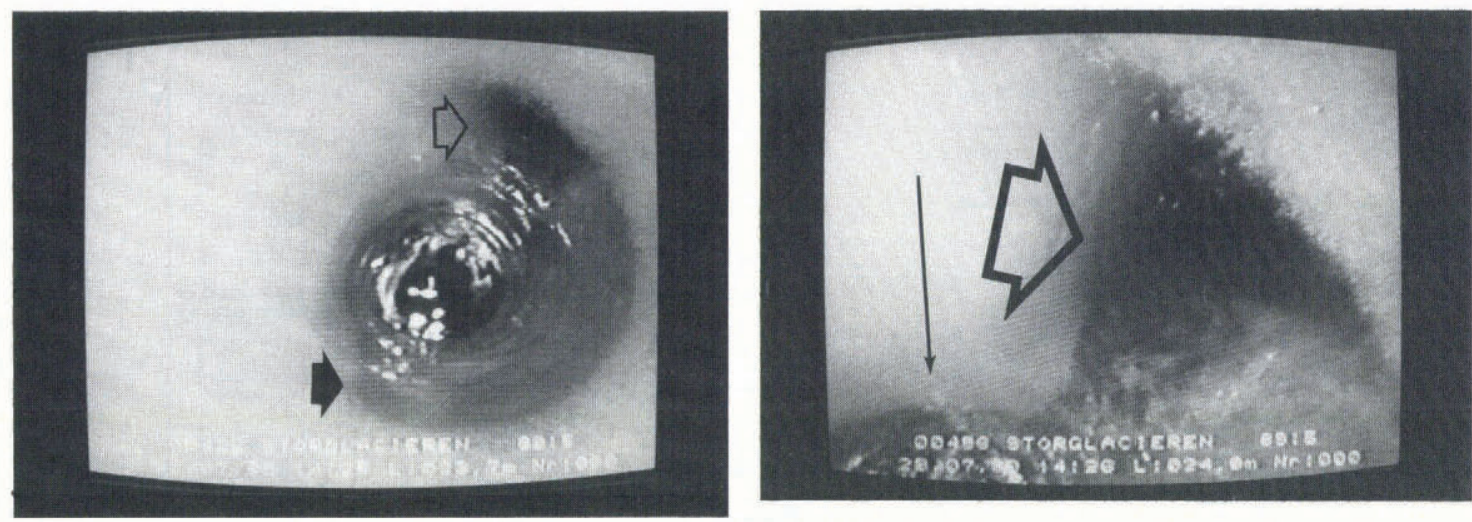

a

b
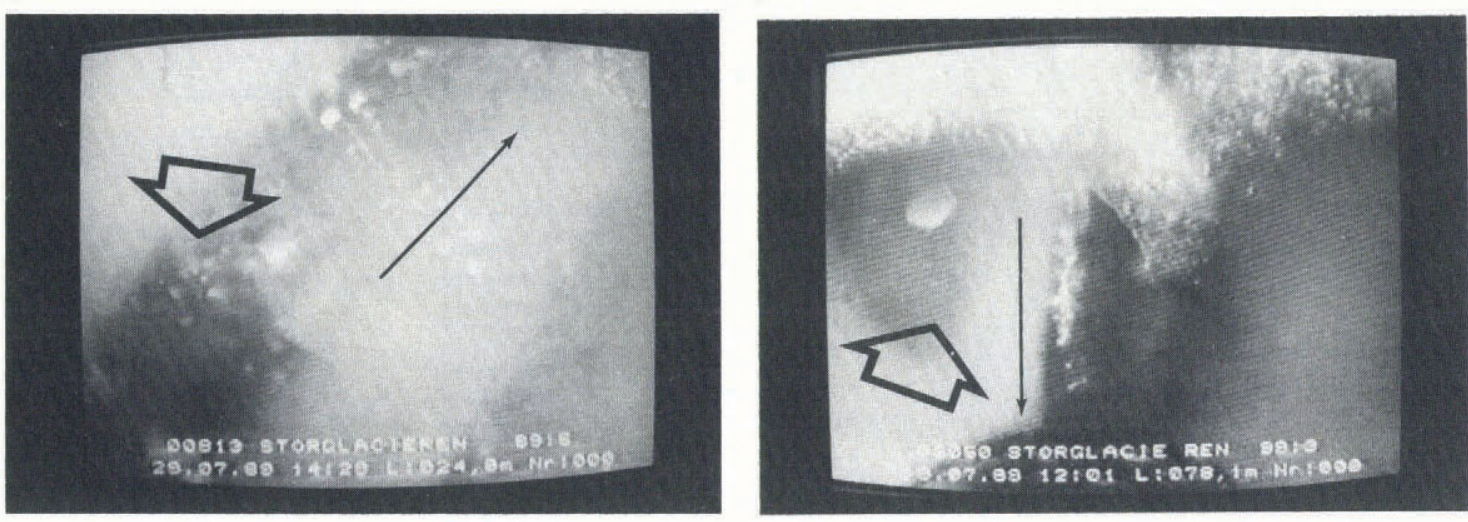

c

d

Fig. 5. Photographs of tubular openings in the borehole walls. The thin arrow points to the bed and the wide arrow shows the openings. a. Borehole 89:5, $23.7 \mathrm{~m}$ depth. Overview of an asymmetrical blue-ice inclusion. The water surface in the borehole is seen reflecting the light from the camera. The tubular opening is indicated by the open arrow and the location of the jagged opening is indicated by the black arrow. b. Borehole 89:5, 24.0 m depth. Close-up scene of the opening depicted in Figure 5a. The opening is about $20 \mathrm{~cm}$ deep and $10 \mathrm{~cm}$ wide. During the inspection, it was observed how water dripped out from the opening. c. Borehole 89:5, 24.0 m depth. The wide arrow points at the opposite opening to that shown in Figure 5b. The opening is of the jagged form. $d$. Borehole 89:3, 78.1 m depth. Close-up of a tubular opening. To the right in the photograph is an asymmetric blue-ice area. This opening is situated just below the sediments shown in Figure $8 a$ and b. The opening diameter was about $20 \mathrm{~cm}$.

equal to the water level in the borehole. Jagged forms were obviously not influenced by the probable smoothing action of warm water, indicating that they may be isolated voids.

\section{Regarding the origin of voids/channels and blue- ice inclusions}

Can the origin of voids/channels and blue-ice inclusions be explained with the help of the observations reported here? Observations of blue-ice bands on the ice surface by P. Holmlund (personal communication) (Fig. 1) revealed that frozen conduits were associated with the banding. The traces of the conduits were found to be of highest frequency within the blue-ice bands, with decreasing frequency with distance from the band. This observation suggests a relationship between englacial channels and blue-ice areas. The blue ice observed by Holmlund is probably the same type of feature as the thick blue-ice inclusions observed in the boreholes, which also showed a relation to the voids/channels and blue ice. Two possible explanations of how this relation might develop will now be discussed: the firn concept and the crevasse concept.
Both possible explanations assume that the origin of this relation is to be found in the accumulation area of the glacier.

The firn concept involves the formation of the blue-ice inclusions by refreezing of water in the firn. The development of ice lenses in firn was studied by Bazhev (1973) who reported that lenses up to $0.5 \mathrm{~m}$ thick were formed by percolating water during an ablation season in a glacier on Mount Elbrus, Caucasus Range. Some of the percolating water froze instantly when cold areas in the firn-pack were reached, but a considerable part of the water remained in a fluid state until the winter cold wave cooled the pack. This can form spatially extensive lenses in the firn-pack, which upon further burial and metamorphosis will form blue-ice inclusions. Bazhev also observed that water moved horizontally above impermeable horizons in the firn. This observation may explain how channels are formed. If the firn is soaked with liquid water, if the potential gradient in the water is high enough and if the firn is porous enough, channelized drainage could develop within the firn-pack. These channels may develop into a channel system by capturing the channel branches downstream. These 
Table 1. Observed englacial voids

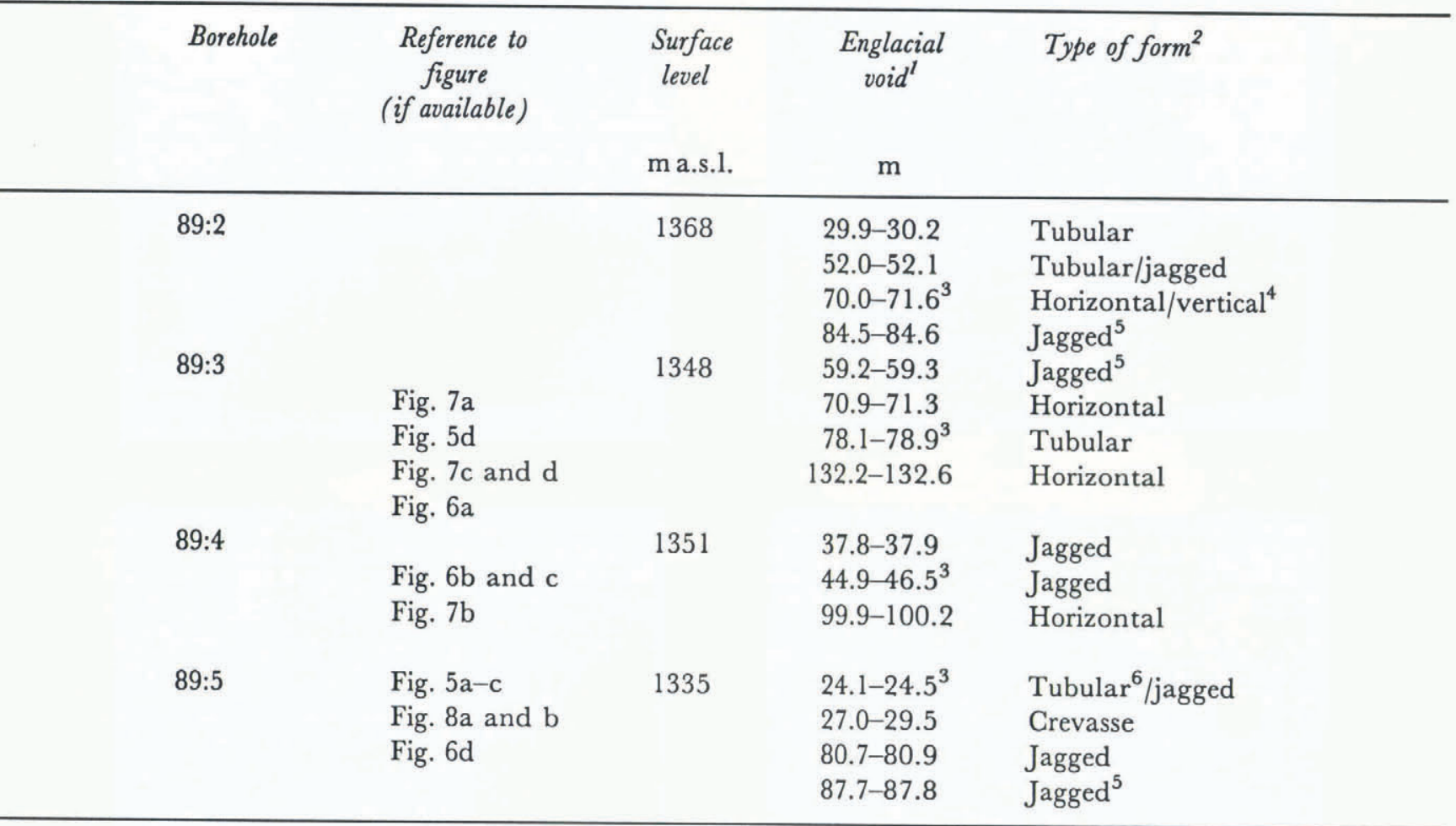

\footnotetext{
${ }^{1}$ The depths are given as depth from the surface of the boreholes.

${ }^{2}$ Slash denotes whether corresponding smaller opening was of another form than the major opening.

${ }^{3}$ The interval denotes the depth within which several voids were found.

${ }^{4}$ The horizontal form had a vertical length of about $0.3 \mathrm{dm}$ and the vertical form had an area of about $1 \mathrm{dm}^{2}$.

${ }^{5}$ Bad view of the form.

${ }^{6}$ The tubular form had a vertical length of about $2 \mathrm{dm}$.
}

a
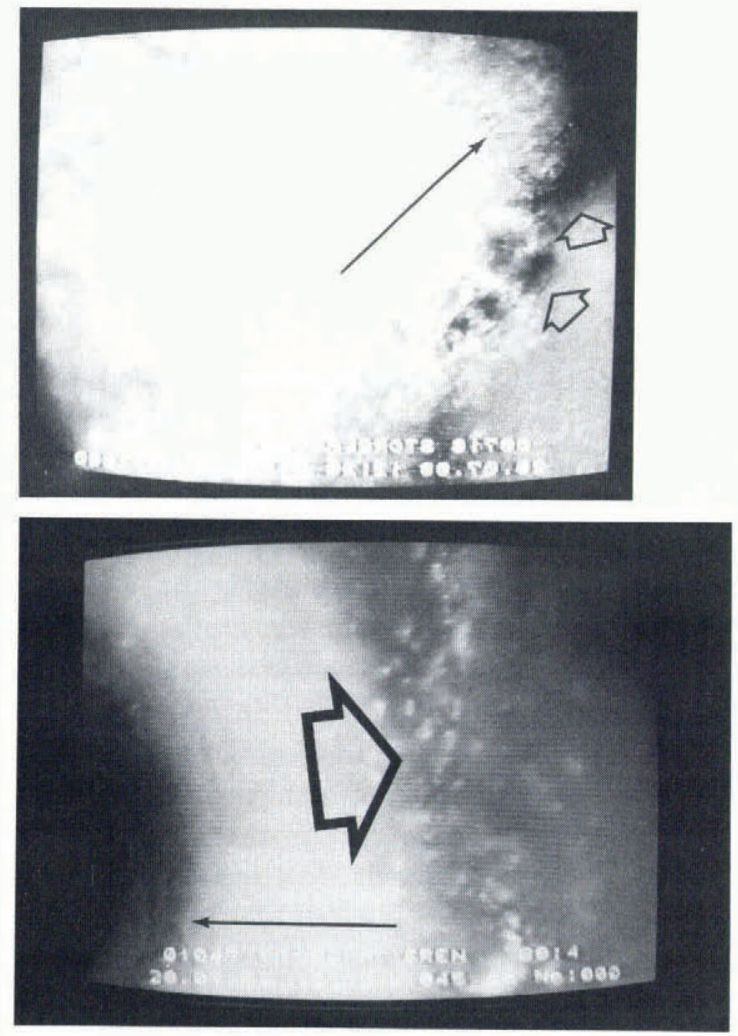

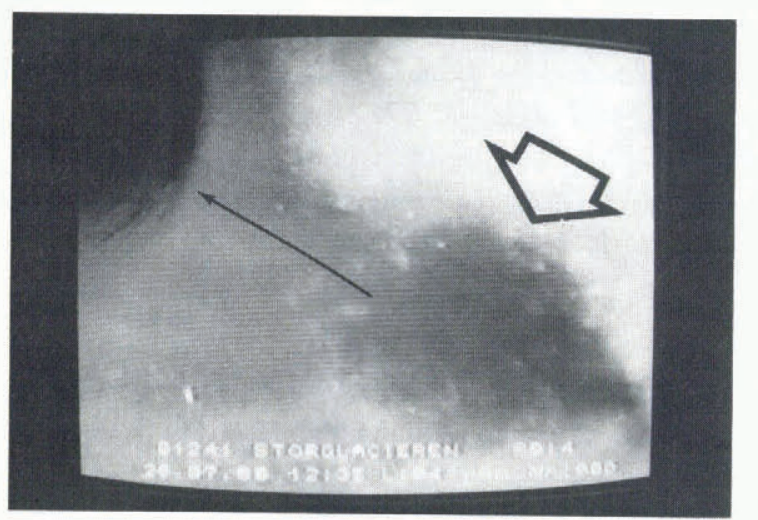

b

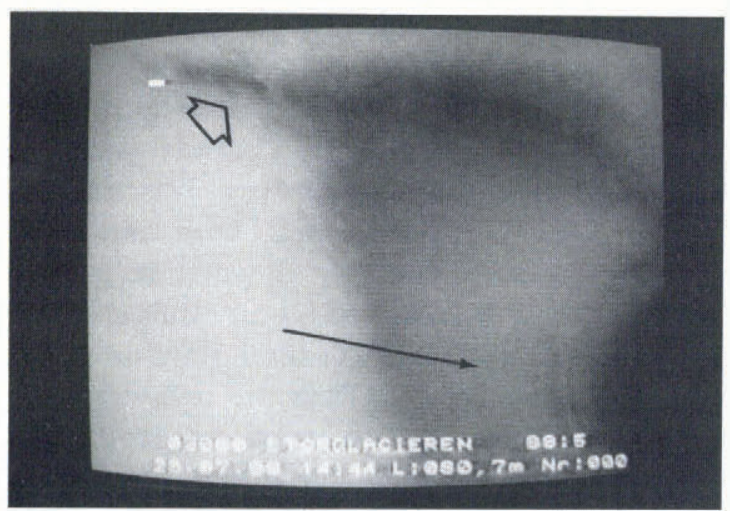

Fig. 6. Photographs of openings in the borehole walls with a jagged form. The thin arrow points to the bed and the wide arrow shows the openings. a. Borehole 89:4, 37.9 m depth. Close-up of a small opening in the wall. It continues as a small crack (about $1 \mathrm{~cm}$ thick) into the white-ice zone. Below the opening a blue-ice inclusion was observed. $b$. Borehole 89:4, $44.0 \mathrm{~m}$ depth. Below the opening is a blue-ice inclusion. $c$. Borehole 89:4, 45.4 m depth. The darker righthand side of the picture shows an opening, which has more extensive horizontal dimensions than in Figure $4 a$ and $b$. The opening appears to be a previous foliation band. $d$. Borehole $89.5,80.7 \mathrm{~m}$ depth. The opening is of the same shape and size as shown in Figure

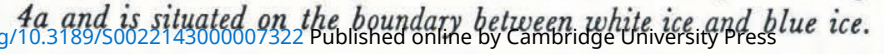




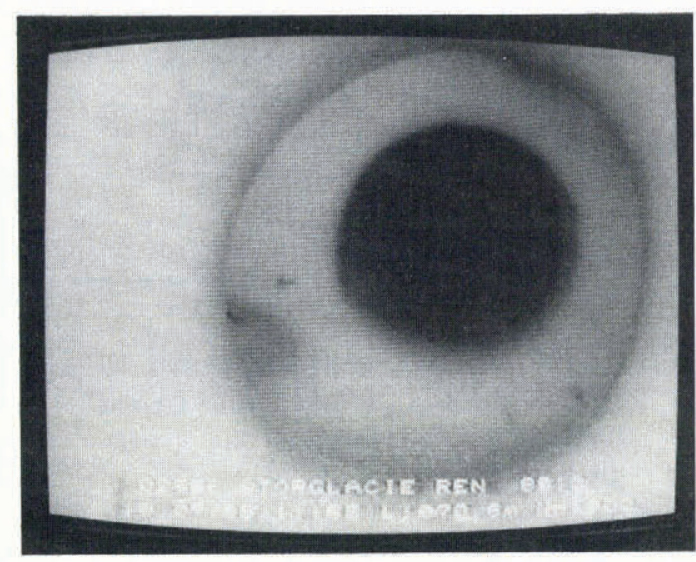

a

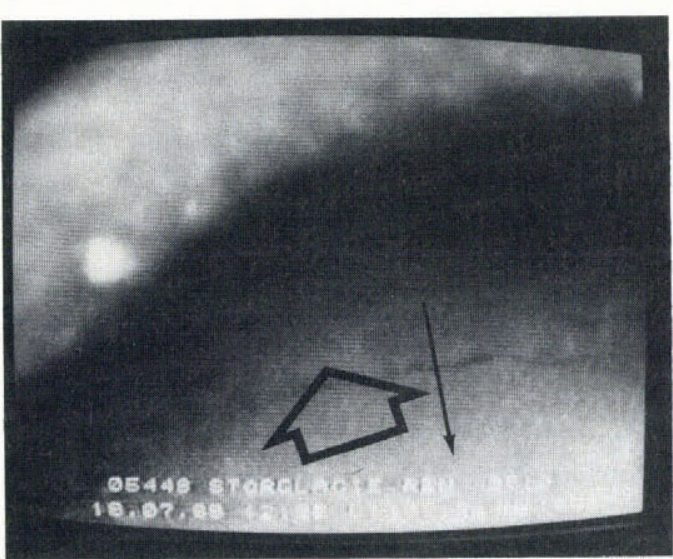

c

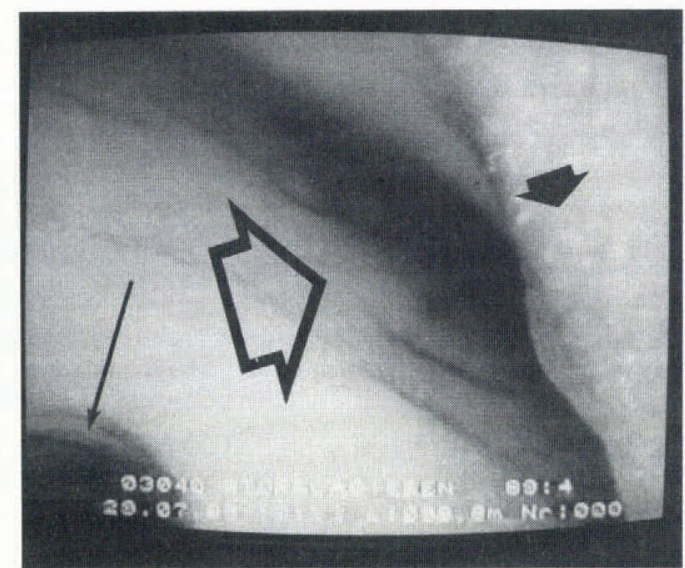

b

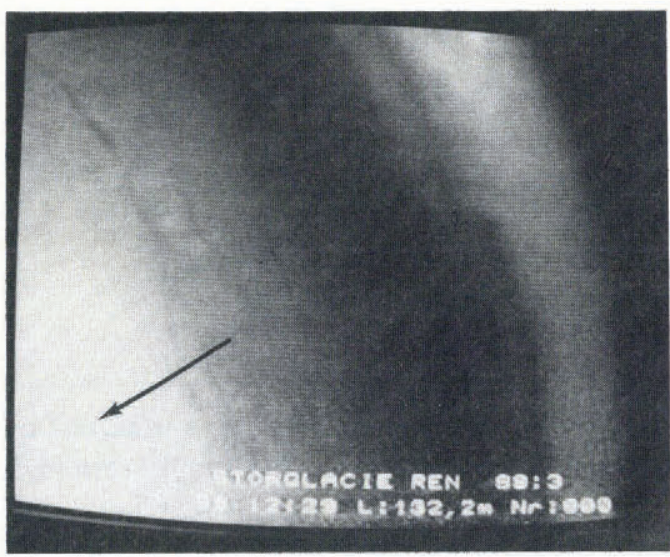

d

Fig. 7. Photographs of openings in the borehole walls of horizontal cleavage form. The thin arrow points to the bed and the wide arrow shows the openings. a. Borehole 89:3, 70.6m depth. A typical view just above an opening of a horizontal cleavage. The opening has horizontal dimensions greater than the dimensions of the borehole $(20 \mathrm{~cm})$. The dark circle is the unlit continuation of the borehole. A close-up view is shown in Figure 2c. b. Borehole 89:4, 99.8m depth. A side view of a horizontal cleavage. The black arrow marks the borehole wall just above the level where the cleavage opened. $c$. Borehole 89:3, $132.2 \mathrm{~m}$ depth. Close-up of a side view of a horizontal cleavage. The light arc in the upper part of the photograph is the borehole wall and the lower light area is the floor of the opening. d. Borehole 89:3, $132.2 \mathrm{~m}$ depth. A side view about $180^{\circ}$ in the horizontal plane from Figure $7 c$ showing the extent of the opening.

channels would, by this concept, be situated in white ice, just above a contact with an ice lens (or blue-ice inclusion).

An alternative concept is that crevasses in the accumulation area serve as water reservoirs, and that the blue-ice inclusions are products of freezing within them. Observations by Fountain (1989) indicated that crevasses in the firn area of South Cascade Glacier, Washington, act as sinks for water in firn. Water seeps from the firn into the crevasses, which, with time and favorable conditions, could build up a water reservoir. The inflow of water will be replaced by an outflow if the water table in the surrounding firn at some stage drops to a lower level. The water flow out from the reservoir into the firn may, as in the firn concept, be channelized flow. It is possible that the channels are initiated at some zone of weakness in the firn. From the observations of jagged voids, it seems that the contact between firn (or white ice) and ice lenses (blue ice) is an example of such a weakness zone. During colder periods, water will gradually freeze in the crevasse and with time this will create blue-ice inclusions. The subsequent burial and the horizontal transport of the crevasse will close the contact with the surface. This could cause the crevasse to develop into an englacial water-filled void (Weertman, 1973), and the channel or channel system developed from the crevasse would become inactive. To remain active, the channel needs water input. A possibility is that the channel may receive water from a younger crevasse up-glacier. The channels formed by this concept would be found within either blue-ice inclusions (inside frozen crevasses) or in white ice (conduits trending out from crevasses).

The borehole observations do not give unambiguous evidence of which concept is the correct model for the origin of channels/voids and blue-ice inclusions. The observed jagged voids could fit either of the two explanations. Of the four observed tubular voids, one was situated on top of a blue-ice inclusion (Fig. 5a-c), one was situated within a blue-ice inclusion (Fig. 5d), and the other two were found within white ice (the thin coating of blue ice observed around the openings was probably an effect of freezing on to the channel wall). The crevasse origin appears to be a better explanation than the firn origin for at least three of these four cases involving 


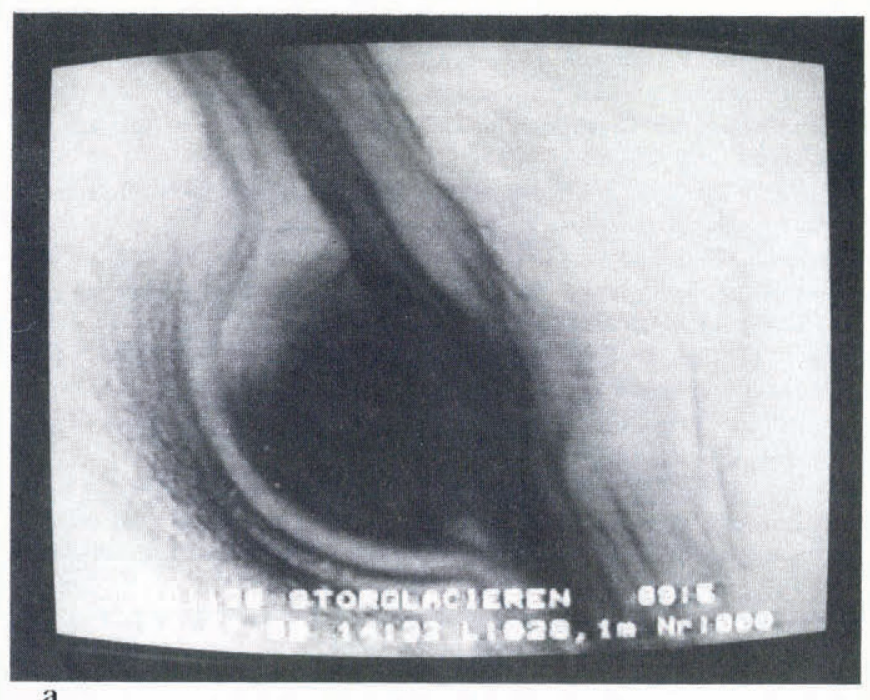

a

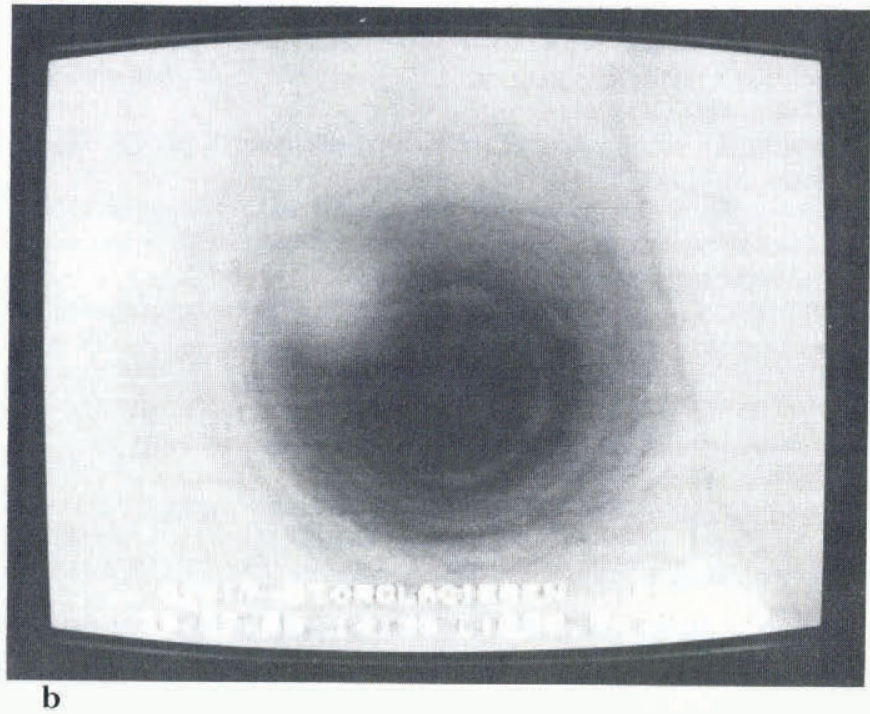

Fig. 8. Photographs of a crevasse intersected by a borehole. a. Borehole 89:5, 28.1 $\mathrm{m}$ depth. The intersected crevasse is about $10 \mathrm{~cm}$ wide at this depth. The crevasse was first observed at $27.0 \mathrm{~m}$ depth and its opening on the glacier surface was found about $5 \mathrm{~m}$ downstream of the borehole. $b$. Borehole 89:5, $29.2 \mathrm{~m}$ depth. The width of the crevasse decreased with depth and here it is shown to continue as a narrow crack into the ice.

tubular voids. The cleavage forms are difficult to explain by the firn concept, but they can be more easily understood by viewing them as unfrozen and open parts of crevasses. The survival of englacial conduits can be more easily comprehended if they originated from waterfilled crevasses. It is difficult to understand how sufficient water could be supplied by a firn-pack that is freezing and losing liquid water. However, a system of connected, water-filled crevasses could supply enough water to feed such a conduit system. Furthermore, the surface observations of conduits which are associated with the blue-ice banding supports the idea that crevasses are the major origin of blue-ice inclusions and englacial voids/channels.

According to this discussion of the crevasse concept, the observed blue-ice inclusions (and the arcuate banding on the surface) should be the frozen traces of crevasses or channels emerging from crevasses. Tubular forms may represent these channels. Cleavage forms may be unfrozen and still open parts of crevasses. Some of the channels have remained open during transport through the glacier and are presumed to be active parts of the englacial drainage system. Others have been closed by freezing. Heat loss from water flowing in an englacial channel due to a pressure drop induced by an adverse slope of the bed topography could possibly fill the conduits with frazil ice (Lawson and Brockett, 1990; Hooke and Pohjola, 1994). This process could lead to clogging and freezing of channels, the creation of isolated cavities and a loss of hydraulic connection with the general englacial network.

\section{CONCLUSIONS}

This study has shown that englacial voids are common features in the upper ablation area of Storglaciären, with an apparent void ratio of $1.3 \%$ of the observed part of the ice column. The voids are interpreted as channels connected to, or cavities originated from, an englacial drainage system. This shows the existence of an extensive englacial hydraulic system in the glacier. A key to the origin of the channel system is the observed correspondence between the blue-ice inclusions and englacial cavities and channels. It is suggested that crevasses in the accumulation area are an important factor in the formation of both blue-ice inclusions and the englacial channels.

\section{ACKNOWLEDGEMENTS}

I am most grateful to all persons and organizations that gave initial stimulation, intellectual and technical support, and financial possibilities to fulfill this work. In particular, I owe my gratitude to Professors R. LeB. Hooke, T. Stenborg and W. Karlén; to J. Kohler, M. Kennett and S. Tatham; to the glaciological "inquisition" at Stockholms Universitet (A. Bodin, H. Grudd, J. -O. Näslund and P. Holmlund). The field work was assisted by D. Moen, L. Jonsson and S. Troëng. The final draft of the paper was improved by the critical comments of $\mathrm{K}$. Echelmeyer and three anonymous reviewers. Funds were provided by the Swedish Natural Science Research Council (NFR), Andréefonden, Helge Ax:son Johnsons Stiftelse, Föreningen Norden, Axel Hambergs testamentesfond, Stiftelsen Lars Hiertas minne and Svenska Turistföreningens fond för vetenskapliga undersökningar.

\section{REFERENCES}

Bamber, J. L. 1988. Enhanced radar scattering from water inclusions in ice. J. Glaciol., 34(118), 293-296.

Bazhev, A. B. 1973. Infiltration and run-off of melt water on glaciers. International Association of Scientific Hydrology Publication 95 (Symposium at Cambridge 1969-Hydrology of Glaciers), 245-250.

Björnsson, H. 1981. Radio-echo sounding maps of Storglaciären, Isfallsglaciären and Rabots glaciär, northern Sweden. Geogr. Ann., 63A(3-4), 225-231.

Clarke, G. K. C. 1987. A short history of scientific investigations on glaciers. 7. Glaciol., Special Issue, 4-24.

Fountain, A.G. 1989. The storage of water in, and hydraulic characteristics of, the firn of South Cascade Glacier, Washington State, U.S.A. Ann. Glaciol., 13, 69-75. 
Fountain, A.G. 1992. Subglacial water flow inferred from stream measurements at South Cascade Glacier, Washington, U.S.A. F. Glaciol., 38(128), 51-64.

Hodge, S. M. 1976. Direct measurement of basal water pressures: a pilot study. F. Glaciol., 16(74), 205-218.

Holmlund, P. 1987. Mass balance of Storglaciären during the 20th century. Geogr. Ann., 69A(3-4), 439-447.

Holmlund, P. 1988a. An application of two theoretical melt water drainage models on Storglaciären and Mikkaglaciären, northern Sweden. Geogr. Ann., 70A(1-2), 1-7.

Holmlund, P. 1988b. Internal geometry and evolution of moulins, Storglaciären, Sweden. F. Glaciol., 34(117), 242-248.

Holmlund, P. and M. Eriksson. 1989. The cold surface layer on Storglaciären. Geogr. Ann., 71A(3-4), 241-244.

Holmlund, P. and R. LeB. Hooke. 1983. High water-pressure events in moulins, Storglaciären, Sweden. Geogr. Ann., 65A(1-2), 19-25.

Hooke, R. LeB. 1991. Positive feedbacks associated with erosion of glacial cirques and overdeepenings. Geol. Soc. Am. Bull., 103(8), 1104 1108.

Hooke, R. LeB. and V.A. Pohjola. 1994. Hydrology of a segment of a glacier situated in an overdeepening, Storglaciären, Sweden. $\mathcal{F}$. Glaciol., 40(134), 140-148.

Hooke, R. LeB., S.B. Miller and J. Kohler. 1988. Character of the englacial and subglacial drainage system in the upper part of the ablation area of Storglaciären, Sweden. F. Glaciol., 34(117), 228-231.

Hooke, R. LeB., P. Calla, P. Holmlund, M. Nilsson and A. Stroeven. 1989. A 3 year record of seasonal variations in surface velocity, Storglaciären, Sweden. 7. Glaciol., 35(120), 235-247.

Hooke, R. LeB., T. Laumann and J. Kohler. 1990. Subglacial water pressures and the shape of subglacial conduits. F. Glaciol., 36(122), 67-71.

Jacobel, R.W. and S. K. Anderson. 1987. Interpretation of radio-echo returns from internal water bodies in Variegated Glacier, Alaska, U.S.A. F. Glaciol., 33(115), 319-323.

Lawson, D.E. and B.E. Brockett. 1990. In-situ sampling and characterization of frazil ice deposits. Cold Reg. Sci. Technol., 17(3), 193-205.

Mathews, W. H. 1964. Water pressure under a glacier. F. Glaciol., 5(38), 235-240.

Nye, J. F, 1989. The geometry of water veins and nodes in polycrystalline ice. F. Glaciol., 35(119), 17-22.
Nye, J.F. and F. C. Frank. 1973. Hydrology of the intergranular veins in a temperate glacier. International Association of Scientific Hydrology Publication 95 (Symposium at Cambridge 1969-Hydrology of Glaciers), 157-161.

Pohjola, V.A. 1993. TV-video observations of bed and basal sliding on Storglaciären, Sweden. J. Glaciol., 39(131), 111-118.

Raymond, C.F. and W.D. Harrison. 1975. Some observations on the behavior of the liquid and gas phases in temperate glacier ice. $\mathcal{F}$. Glaciol., 14(71), 213-233.

Savage, J. C. and W. S. B. Paterson. 1963. Borehole measurements in the Athabasca Glacier. F. Geophys. Res., 68(15), 4521-4536.

Schytt, V. 1959. The glaciers of the Kebnekajse-Massif. Geogr. Ann., 41(4), 213-227.

Seaberg, S.Z., J.Z. Seaberg, R. LeB. Hooke and D. Wiberg. 1988. Character of the englacial and subglacial drainage system in the lower part of the ablation area of Storglaciären, Sweden, as revealed by dye-trace studies. F. Glaciol., 34(117), 217-227.

Shreve, R. L. 1972. Movement of water in glaciers. F. Glaciol., 11(62), 205-214.

Shreve, R. L. and R. P. Sharp. 1970. Internal deformation and thermal anomalies in lower Blue Glacier, Mount Olympus, Washington, U.S.A. F. Glaciol., 9(55), 65-86.

Stenborg, T. 1965. Problems concerning winter run-off from glaciers. Geogr. Ann., 47(3), 141-184.

Stenborg, T. 1969. Studies of the internal drainage of glaciers. Geogr. Ann., $51 \mathbf{A}(1-2), 13-41$.

Stenborg, T. 1973. Some viewpoints on the internal drainage of glaciers. International Association of Scientific Hydrology Publication 95 (Symposium at Cambridge 1969-Hydrology of Glaciers), 117-129.

Walford, M.E. R. and M. I. Kennett. 1989. A synthetic-aperture radioecho experiment at Storglaciären, Sweden. J. Glaciol., 35(119), 4347.

Watts, R.D. and A.W. England. 1976. Radio-echo sounding of temperate glaciers: ice properties and sounder design criteria. $\mathcal{f}$. Glaciol., 17(75), 39-48.

Weertman, J. 1973. Can a water-filled crevasse reach the bottom surface of a glacier? International Association of Scientific Hydrology Publication 95 (Symposium at Cambridge 1969-Hydrology of Glaciers), 139-145.

The accuracy of references in the text and in this list is the responsibility of the author, to whom queries should be addressed. 